\title{
Mit kell tudnunk a cardialis amyloidosisról?
}

\author{
A tünettantól a kezelésig
}

\author{
Földeák Dóra dr. ${ }^{1}$ - Nemes Attila dr. ${ }^{1}$ - Kalapos Anita dr. ${ }^{1}$ \\ Domsik Péter dr. ${ }^{1}$ - Kormányos Árpád dr. ${ }^{1}$ - Krenács László dr. ${ }^{2}$ \\ Bagdi Enikő dr. ${ }^{2}$ - Borbényi Zita dr. ${ }^{1}$ \\ ${ }^{1}$ Szegedi Tudományegyetem, Általános Orvostudományi Kar, Szent-Györgyi Albert Klinikai Központ, \\ II. Belgyógyászati Klinika és Kardiológiai Központ, \\ ${ }^{2}$ Daganatpatológiai és Molekuláris Diagnosztikai Laboratórium, Szeged
}

\begin{abstract}
A szisztémás amyloidosis ritka betegség, amelyben a szívérintettség viszonylag gyakran fordul elő és a túlélést jelentősen befolyásolja. Az alapbetegség és a szervi érintettség szempontjából új diagnosztikus eljárások segítenek a korai diagnózis felállításában és a mihamarabbi kezelés megkezdésében. Szivérintettség inkább a monoklonális immunglobulin-könnyuulánc (AL-amyloidosis) és a transthyretin formában fordul elő. AL-amyloidosis esetén a szívérintettség súlyos következményekhez vezet. A kezdeti súlyosság megítélésében és a kezelésre adott válasz mértékének mérésében a szívfunkcióval kapcsolatos biomarker-vizsgálatok segítenek. Amyloidosis esetén az életkorral nő a szívérintettség, a prevalencia nem ismert pontosan, de feltételezhető, hogy több eset van valójában, mint amennyi felismerésre kerül. A szerzők a klinikai tünetek, diagnosztikus eljárások, kiemelten a kardiológiai vizsgálatok jelentőségét ismertetik.

Orv Hetil. 2017; 158(46): 1811-1818.
\end{abstract}

Kulcsszavak: cardialis, amyloidosis, echokardiográfia, immunglobulin-könnyúláncok

\section{What should we know about cardiac amyloidosis? \\ From clinical signs to treatment}

Systemic amyloidosis is a rare disease, in which the heart involvement is rather frequent and determines survival remarkably. Regarding the disease and organ involvement, new diagnostic procedures help to establish the diagnosis and to start the adequate treatment as soon as possible. Cardiac involvement is more likely to be characterised by monoclonal immunglobulin free light chain (AL amyloidosis) type and transthyretin type. In case of AL amyloidosis, heart involvement can lead to serious consequences. Biomarker assessments for cardiac function are important to determine disease severity at the beginning and to measure response to the treatment. In case of amyloidosis, the incidence of the heart involvement grows with age. The prevalence is not known exactly, but probably there are more cases than recognised. The authors present the clinical signs and diagnostic methods, emphasizing the importance of the cardiac examination methods.

Keywords: cardiac, amyloidosis, echocardiography, immunglobulin light chains

Földeák N, Nemes A, Kalapos A, Domsik P, Kormányos Á, Krenács L, Bagdi E, Borbényi Z. [What should we know about cardiac amyloidosis? From clinical signs to treatment]. Orv Hetil. 2017; 158(46): 1811-1818.

(Beérkezett: 2017. augusztus 2.; elfogadva: 2017. szeptember 7.) 


\section{Rövidítések}

AA-amyloidosis = amyloid A fehérje amyloidosis; $\mathrm{AApoAl}=$ amyloid apoliprotein Al típus; AL-amyloidosis = monoklonális immunglobulin-könnyúlánc amyloidosis; ATTR = transthyretin amyloidosis; AV-blokk = atrioventricularis blokk; CTD = cyclophosphamid + thalidomid + dexamethason; $\mathrm{cTnT}=$ cardialis troponin T; EKG = elektrokardiogram; GFR = glomeruláris filtrációs ráta; $\mathrm{ICD}=$ (implantable cardioverter defibrillator $)$ beültethető kardioverter defibrillátor; MGUS = (monoclonal gammopathy of undetermined significance) tisztázatlan jelentôségú monoklonális gammopathia; MRI $=$ (magnetic resonance imaging) mágneses rezonanciás vizsgálat; NT-proBNP = $\mathrm{N}$-terminal pro-brain natriuretic peptide precursor; NYHA = New York Heart Association; SAP = szérum-amyloid-P; VGPR $=($ very good partial response $)$ nagyon jó parciális válasz

A szisztémás amyloidosis a ritka betegségek csoportjába tartozik, amelyet a nem oldódó fehérjefibrillumok extracelluláris szöveti lerakódása jellemez. A fibrillumok különböző prekurzor fehérjékből származnak és adott szövetek szerkezetét károsítják, létrehozva ezzel annak diszfunkcióját. Számos örökletes és szerzett forma különíthető el. Az amyloidlerakódás többféle módon jöhet létre: előfordulhat egy kóros fehérje jelenlétében, mint a szerzett szisztémás immunglobulin-könnyưlánc (AL) amyloidosis, ami a leggyakoribb típus. Társulhat inflammatórikus betegségekhez, például krónikus gyulladásos vagy fertőzéses kórképekhez. Ez az úgynevezett szekunder amyloidosis, amikor az amyloid A fehérje (AA) rakódik le. Előfordul örökletes forma, legismertebb a transthyretin amyloidosis (ATTR), de idetartozik az apolipoprotein A-I és A-II, valamint a fibrinogén-alfalánc forma is. Létrejöhet egy normális fehérje hosszú ideje fennálló jelenlétével kapcsolatban (reaktív szisztémás amyloidosis és béta-2-microglobulin dialízishez társult amyloidosis), illetve az öregedési folyamat részeként (vad típusú transthyretin) vagy szenilis szisztémás amyloidosis).

Az immunglobulin-könnyúlánc (AL) amyloidosis a szisztémás amyloidosis leggyakoribb formája. Az immunglobulin-könnyúláncot a csontvelőben található klonális plazmasejtek termelik. Tekintettel arra, hogy a megjelenési forma nagyon változatos, a diagnózis gyakran késleltetett. Eddig legalább 30-féle fehérjét azonosítottak a kórkép létrejöttében [1], de tömegspektrometriai mérések arra utalnak, hogy még ennél is több fehérje játszhat szerepet a kialakulásában [2]. A szövettani diagnózis alapját a kongóvörösfestés és a polarizációs mikroszkópia segítségével látható zöldes kettős fénytörés adja. A fehérje típusának pontos meghatározása tömegspektrométerrel lehetséges, amelyre Magyarországon egyelőre nincs lehetőség. A kezelés több szakma együttes munkáját igényli, kardiológus, nefrológus és hematológus közremúködésével.

Az érintett szervek között szerepelhet a szív is, amely prognosztikai értékkel bír. Az amyloidlerakódás a szívben, értelemszerüen annak kontraktilis funkciójának romlásához vezet. Az amyloidosis több típusában is előfordulhat szívérintettség, mely restriktív cardiomyopathiához vezethet és a prognózis szempontjából meghatározó tényező. Számos esetben a diagnózis későn születik meg, a betegség korai szakaszában az elektrokardiogram (EKG) és a szívultrahang-vizsgálat nem mindig mutat specifikus eltéréseket. Cardialis mágneses rezonanciás vizsgálat (MRI) elvégzése javasolt, amennyiben felmerül a szívamyloidosis lehetősége. A prognózis és a kezelés a betegség különböző típusától függ.

\section{Patofiziológia}

Az amyloidosist az amyloid prekurzor fehérje azonosításával tudjuk osztályozni. A depozitumok glükózaminoglikánokat, apolipoproteineket és szérum-amyloid-P összetevőt (SAP) tartalmaznak $[3,4]$. A fehérje térszerkezeti változásoknak köszönhetően oldhatatlan amyloidfibrillumok rakódnak le az extracelluláris térben, amelyek béta-lemezes szerkezetűek. Az amyloidfibrillumok jellegzetessége, hogy olyan speciális formában kötik a kongóvörös festéket, hogy az polarizált fényben metakromáziát mutat, almazöld fényt ad. A szövettani vizsgálat során a mai napig ezt a módszert alkalmazzák az amyloidosis igazolására. A nem fibrilláris összetevők ismerete speciális képalkotó módszerek, illetve új terápiás célpontok miatt jelentós.

Az AL-amyloidosis a leggyakrabban diagnosztizált amyloidosisforma, amely klonális plazmasejt-szaporulat vagy egyéb, immunglobulin-szekrécióval járó B-sejt-dyscrasia következménye. Az AL-amyloid-fibrillumok könynyưlánc-fragmentumokból épülnek fel, ennek típusa lehet kappa- vagy lambda-könnyúlánc. A csontvelő monoklonális plazmasejtes infiltrációja bizonytalan jelentőségű monoklonális gammopathiaként (monoclonal gammopathy of undetermined significance - MGUS) vagy plazmasejtes myelomaként jelentkezhet. A prognózis myeloma multiplex esetén rosszabb.

\section{Klinikai tünetek}

$\mathrm{Az}$ amyloidlerakódás majdnem minden szervet érinthet, ezért a klinikai megjelenés is sokszínú. Általánosságban elmondható, hogy a gastrointestinalis traktus, a vese, a nyálmirigyek, a zsírszövet, a csontvelő és a szív szerepel a leggyakoribb célpontok között. Vesefunkciós eltérés, albuminuria, súlyosabb esetben nephrosis szindróma is kialakulhat. AL-amyloidosis esetén jellegzetes a macroglossia és periorbitalis bevérzések, amelyek az esetek egyharmadában fordulnak elő. A cardialis érintettség nagyban meghatározza a mortalitást [4], AL-amyloidosis esetén a szív az esetek legalább 50\%-ában érintett [5]. AA-amyloidosis esetén jellemző a proteinuria vagy vesemúködés-eltérés, kivételesen ritka, ha a vese nem érintett ebben a típusban [5]. Az egyéb amyloidosistípusokat illetően a wild-type és variáns ATTR esetén domináló tünet a szív érintettsége, örökletes AApoAl típusban na- 
gyon jellemző, AA- (amyloid A fehérje, gyulladásos típus) amyloidosisban igen ritka [6]. Jellemző tünet még a perifériás neuropathia, ami döntően axonalis, mind a kis, mind a nagy rostokat is érinti. Autonóm neuropathia impotenciát okozhat, a posturalis hypotonia, hasmenés vagy székrekedés ugyancsak gyakori jelenség. Gyakori és korai jel lehet a carpal-tunnel szindróma. Az amyloidlerakódás a szívben restriktív cardiomyopathiát okozhat, általában jobbszívfél-elégtelenséggel (ödéma, emelkedett jugularis vénás nyomás és pangásos hepatomegalia), előrehaladott betegségben low cardiac output és hypotonia alakul ki. AL-amyloidosis esetében a klinikai tünetek kifejezettebbek, amit a könnyúlánc-lerakódás myocardialis sejtekre való toxikus hatása magyarázhat $[7,8]$.

\section{Diagnosztika}

A diagnózis felállításához rendelkezésünkre álló fontosabb eljárások és azok klinikai, diagnosztikus jelentősége az alábbiakban kerül összefoglalásra.

\section{Biomarker-pizsgálatok}

Cardialis stressz hatására számos hormonszerü anyag kerül kibocsátásra ( $\mathrm{N}$-terminal pro-brain natriuretic peptide prekurzor [NT-proBNP], cardialis troponin $\mathrm{T}$ [cTnT]), így ezek az anyagok nem specifikus indikátorai lehetnek a cardialis diszfunkciónak. AL-amyloidosis esetén a kardiológiai biomarkerek szoros korrelációban állnak a prognózissal, a terápiás hatás megítélésével [9].
1. táblázat $\mid$ Mayo revised prognostic staging kritériumrendszer

\begin{tabular}{lllll}
\hline & $\begin{array}{l}\mathrm{cTnT} \geq 0,025 \\
\mathrm{ng} / \mathrm{ml}\end{array}$ & $\begin{array}{l}\text { NT-proBNP } \geq \\
1800 \mathrm{ng} / \mathrm{L}\end{array}$ & $\begin{array}{l}\text { sFLC } \geq 180 \\
\mathrm{mg} / \mathrm{L}\end{array}$ & Score \\
\hline I. stádium & 0 & 0 & 0 & 0 \\
II. stádium & $0 \pm 1$ & $0 \pm 1$ & $0 \pm 1$ & 1 \\
III. stádium & $0 \pm 1$ & $0 \pm 1$ & $0 \pm 1$ & 2 \\
IV. stádium & 1 & 1 & 1 & 3 \\
\hline
\end{tabular}

cTnT $=$ cardialis troponin $\mathrm{T}$; NT-proBNP $=\mathrm{N}$-terminal pro-brain natriuretic peptide precursor, $\mathrm{sFLC}=$ szérum-könnyúlánc

A Mayo revised prognostic staging kritériumrendszer van jelenleg használatban, amely a prognózis megítélését segíti, az NT-proBNP-szérumszint, cardialis troponin T-szint és a keringő könnyúlánc-szint meghatározásával [10] (1. táblázat). Az NT-proBNP mind a frissen diagnosztizált betegek esetén, mind pedig a szisztémás kezelést kapott betegek esetén a túlélés egyik mutatója [11]. Emelkedett cardialis troponin T-érték a betegség progresszióját és rossz kimenetelt jelezhet, bár szívérintettség esetén a terápiás válasz becslésével kapcsolatban kevésbé megbízható [12]. Veseelégtelenség esetén az NT-proBNP szintje egyébként is emelkedett lehet, így ezekben a betegekben ennek a markernek a prognosztikus értéke kevésbé megbízható. Az eddigi tapasztalatok azt mutatják, hogy amennyiben a GFR nagyobb, mint $15 \mathrm{ml} / \mathrm{min} /$ $1,73 \mathrm{~m}^{2}$, akkor alkalmas az NT-proBNP-szint a túlélés mutatójának [13].

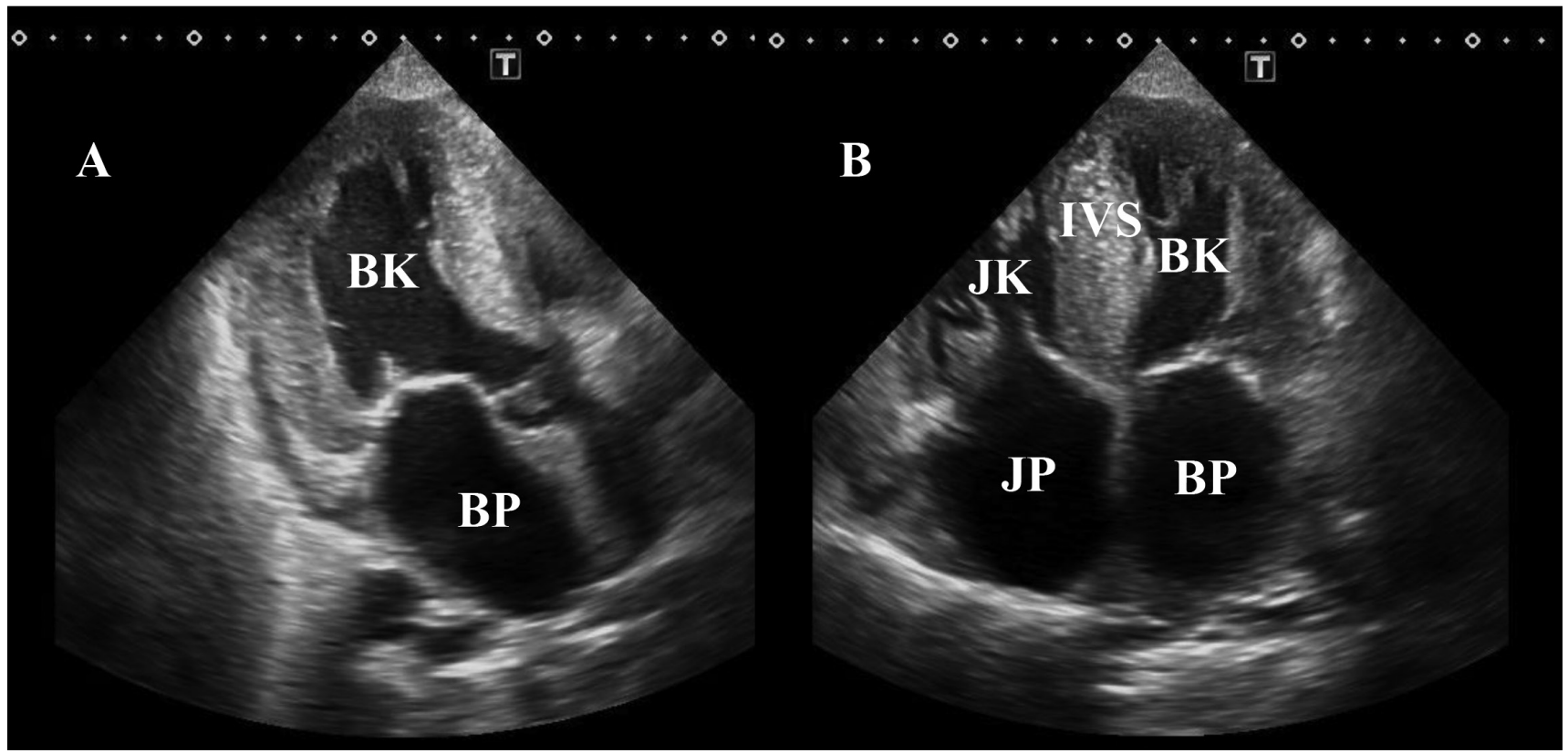

l. ábra $\quad$ Kétdimenziós echokardiográfia során rögzített kétüregi és négyüregi felvétel látható. Cardialis amyloidosisra jellemző a jelentősen megvastagodott kamrai falak és interventricularis septum, a szúk bal kamrai üreg, a tágult pitvarok

$\mathrm{BK}=$ bal karma; $\mathrm{BP}=$ bal pitvar; IVS = interventricularis septum; JK = jobb kamra; JP = jobb pitvar 


\section{Elektrokardiográfia}

AL-amyloidosisban szívérintettség esetén az EKG-n a low voltage, mellkasi elvezetésekben a csökkent R-hullám-progresszió a betegek felénél fordul elő [14]. Az EKG-n látott low voltage és az echokardiográfia során leírt koncentrikus falmegvastagodás felkelti az amyloidosis gyanúját. Előfordulhat még elsőfokú AV-blokk (21\%), nem specifikus intraventricularis vezetési zavar (16\%), másod- vagy harmadfokú AV-blokk (3\%), pitvarfibrilláció/flatter (20\%) és kamrai aritmia (5\%) is [15].

\section{Echokardiográfia}

Szív-ultrahangvizsgálat minden olyan esetben szükséges, amikor felmerül az amyloidosis gyanúja (1. ábra). Gyakran a betegség előrehaladott állapotában látunk csak eltérést. Specifikus lehet a koncentrikus kamrai megvastagodás jobb kamrai érintettséggel, rossz biventricularis funkció normális vagy közel normális ejekciós frakcióval, esetleg pericardialis/pleuralis folyadék jelenlétével [16, 17]. Amyloidosis esetén jellegzetes a „sparkling”, csillámlás jelenség. A diasztolés funkciózavar a legkorábban észlelhető echokardiográfiás eltérés és a klinikai tünetek megjelenése előtt már kimutatható [18, 19]. A szívultrahangvizsgálat eredményét a klinikum függvényében kell értékelni. A diagnózis kulcsa a biatrialis dilatatio, a biventricularis, valvularis és interatrialis septummegvastagodás [18]. A kis kamrai üreg miatt 'low cardiac output' alakulhat ki, amely az intracardialis nyomás emelkedéséhez és tüdő-, valamint szisztémás pangáshoz vezethet. Az extracelluláris amyloidlerakódás sejtszintú múködészavart, oxidatív stresszt és apoptózist hozhat létre. Ezenkívül kisérbetegséghez, illetve ingerületvezetési zavarokhoz, valamint direkt metabolikus diszfunkcióhoz vezethet [20]. A modernebb echokardiográfiás eljárások, mint a speckle-tracking és/vagy háromdimenziós echokardiográfia, lehetővé teszik a szívüregek falmozgá-

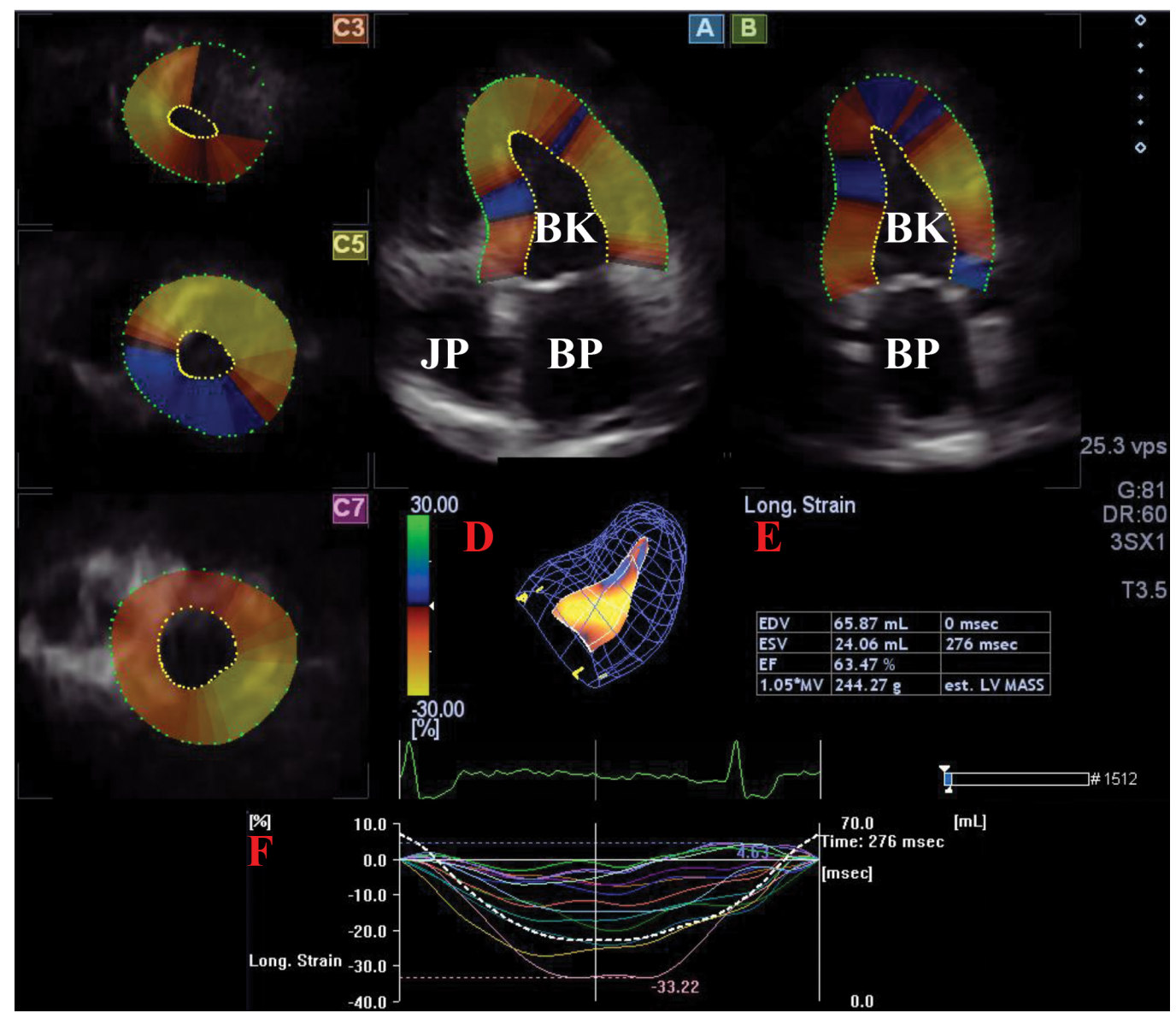

2. ábra

A háromdimenziós (3D) speckle-tracking echokardiográfia alkalmas módszer a szívüregek, kiemelten a bal karma részletes vizsgálatára, mivel egy di-
gitálisan rögzített, a bal kamrát is magába foglaló 3D adatbázis (echoköd) segítségével nemcsak a szívciklusnak megfelelő pontos üregi térfogatválto-
zások, hanem a falmozgások kvantitatív jellemzói, az úgynevezett strainek is egy időben mérhetők. A fentieken túl a különböző bal kamrai szegmen-
sek rotációs képessége is jellemezhetó. A mérésekhez használt speciális szoftver segítségével a begyújtött 3D echoködból kétdimenziós négyüregi (A)
és kétüregi (B) hossztengelyi képet, illetve a bal kamráról három különböző szinten keresztmetszeti képet hozunk létre (C3, C5, C7). A módszer
segítségével a bal kamráról 3D modell készíthető (piros D), valamint térfogat-, ejekciós frakció és izomtömegadatok is nyerhetók (piros E). Beállítás-
tól függóen különbözó strain, displacement, rotációs stb. görbék állíthatók elő (jelen esetben szegmentális longitudinális strain) (piros F)
BK = bal kamra; BP = bal pitvar; JP = jobb pitvar 
sainak kvantitatív jellemzését úgynevezett strainanalízis segítségével (2. ábra). A bal kamra a szívciklus során mintegy kifacsarja saját magát (bal kamrai csavarodás vagy twist), ennek objektív jellemzése is lehetséges ezekkel az új módszerekkel. Bár részletes nagy volumenú vizsgálatok még nem történtek cardialis amyloidosisban ezekkel a vizsgálatokkal, a kezdeti eredmények érdekes és talán a jövőben diagnosztikus jelentőségű eltéréseket találtak: például igen gyakori előfordulásúnak tünik a balkamra-csavarodás hiánya, az úgynevezett bal kamrai merevtest-rotáció cardialis amyloidosis fennállása esetén [21-25].

\section{Cardialis MRI}

A funkcionális és morfológiai jellemzők tekintetében hasonló információt ad, mint a szív-ultrahangvizsgálat, azonban a diasztolés eltérések azonosításában jobb vizsgálómódszer. A globális subendocardialis késői gadolíniumhalmozás igen jellegzetes szívamyloidosisban [26], amely jól korrelál a prognózissal [27]. A cardialis MRI alkalmas arra, hogy balkamra-hypertrophiához vezető más betegségeket elkülönítsen az amyloidosistól [28]. Limitáló tényező lehet a veseelégtelenség, a pacemaker/ defibrillátor megléte, az extrém obesitas és a klausztrofóbia jelenléte.

\section{Szövettani vizsgálat}

Amennyiben felmerül az amyloidosis lehetősége a klinikai kép, az EKG, az echokardiográfiás és biomarkeradatok alapján, akkor szövettanilag igazolni kell annak jelenlétét, és meg kell határozni annak típusát. Mivel az amyloidosis csaknem minden esetben több szervet érint, a mintavétel bármely érintett szervből történhet, például bőr, vese, csontvelő, nyálmirigy, gastrointestinalis traktus, de ritkán a szív is szóba jön. Bőrbiopszia során fontos, hogy a subcutis zsírszövetből történjen a mintavétel. Endomyocardialis biopszia abban az esetben jön szóba, amikor a szívérintettség izolált vagy más vizsgálómódszerrel az amyloid típusa nem állapítható meg. A gyakorlatban elvégzése általában az AL és ATTR típusok közti elkülönítés miatt ajánlott idősebb betegekben. A beavatkozáshoz köthető perforációs komplikáció ritka a szívben.

\section{Rizikófelmérés és staging}

A prognózist a szervkárosodás mértéke határozza meg, leginkább a szívérintettségé. Klinikai tényezők közül a rossz általános állapot, a súlyos posturalis hypotonia, a szívelégtelenség NYHA III-IV. stádium, az alacsony szisztolés vérnyomás (<100 Hgmm) a meghatározó. Laborparaméterek közül az NT-proBNP (>332 ng/l), a cardialis troponin $\mathrm{T}(>0,035 \mathrm{ng} / \mathrm{ml})$ az alapja a Mayo Clinic staging rendszernek [29] (2. táblázat). III. stádi-
2. táblázat | Mayo cardialis staging kritériumrendszer

\begin{tabular}{llll}
\hline & $\begin{array}{l}\mathrm{cTnT} \geq 0,035 \\
\mathrm{ng} / \mathrm{ml}\end{array}$ & $\begin{array}{l}\text { NT-proBNP } \geq 332 \\
\mathrm{pg} / \mathrm{ml}\end{array}$ & \\
\hline I. stádium & Normál szint & Normál szint & $\begin{array}{l}\text { Mindkét érték } \\
\text { normál }\end{array}$ \\
II. stádium & $\begin{array}{l}\text { Normál vagy } \\
\text { emelkedett }\end{array}$ & $\begin{array}{l}\text { Normál vagy } \\
\text { emelkedett }\end{array}$ & $\begin{array}{l}\text { Egyik érték } \\
\text { emelkedett }\end{array}$ \\
III. stádium & Emelkedett & Emelkedett & $\begin{array}{l}\text { Mindkét érték } \\
\text { emelkedett }\end{array}$ \\
\hline
\end{tabular}

cTnT $=$ cardialis troponin $\mathrm{T} ; \mathrm{NT}$-proBNP $=\mathrm{N}$-terminal pro-brain natriuretic peptide precursor

um esetén, amikor mind a két biomarker emelkedett, az átlagos túlélés hét-nyolc hónap [30]. A III-as stádiumba tartozó betegeknél, ha az NT-proBNP-érték >8500 ng/L, a szisztolés vérnyomásérték < $100 \mathrm{Hgmm}$, akkor a túlélés igen rövid (három hónap) [31]. Abban az esetben, ha staging alkalmával magas a könnyúlánc-szint [32], illetve ha a csontvelőben több mint $10 \%$-os a plazmasejtes infiltráció [33], akkor rosszabb túlélésre lehet számítani.

\section{Kezelés}

\section{Alapelvek}

A szívamyloidosisról általánosságban elmondható, hogy rossz prognózisú betegség, de az amyloid típusa és a kezelésre adott válaszadás miatt vannak eltérések. A kezelés alapelve az amyloidfibrillumokat képző prekurzor fehérjék mennyiségének csökkentése. A kezelés eredményességének lemérésekor fontos a csökkenés mértékének, valamint az érintett szervek múködésére kifejtett hatásának ismerete. A legjobb a túlélés azokban a betegekben, akiknél komplett válasz (nincs kimutatható monoklonális immunoglobulin sem a szérumban, sem a vizeletben immunfixációval, és a szabadkönnyúlánc-szint normál tartományban van) vagy nagyon jó parciális válasz (könynyü lánc <40 mg) alakul ki [34]. Szívérintettségben az NT-proBNP-szint 30\%-os vagy 300 ng/L mértékü csökkenése erőteljes választ mutat [31].

Amennyiben megvalósítható, és a beteg állapota lehetôvé teszi, a megfelelő tüneti ellátás (például szívelégtelenség kezelése) mellett három fő kezelési stratégia határozza meg a terápiát. Először indukciós kemoterápia történik, amelynek feladata, hogy eltávolítsa a könnyű láncot termelő plazmasejteket a csontvelőből. Ezután szívtranszplantáció jöhet szóba, amely segít stabil cardiovascularis rendszert létrehozni a nagy dózisú kemoterápia előtt. Majd harmadik lépésként következhet a nagy dózisú melphalan kondicionáló kezelés után az autológ őssejt-transzplantáció [35]. Fontos megjegyezni, hogy csak válogatott esetekben jöhet szóba a fent említett komplex kezelés. Habár nő a teljes túlélés és a válaszadási arány, még mindig jelentős a kezeléshez kötött halálozás [36]. Jelentôs szívérintettség esetén a kezdeti nagy dózi- 
sú kemoterápia kapcsán a szívvel kapcsolatos halálozás magas [35].

Szupportív kezelésként a vérnyomás szoros monitorozása, a folyadékegyensúly fenntartása, alfa-agonisták használata autonóm neuropathia esetén, illetve a megfelelő táplálkozás segíthet. Új terápiás támadáspontok állnak vizsgálat alatt fóleg ATTR esetén, amelyek az amyloidfibrillumok képződését gátolják, direkt módon támadják a lerakódást vagy stabilizálják a prekurzor fehérjét [28].

\section{AL-amyloidosis kezelése}

A kezelés alapköve a kemoterápia, amelynek célja a klonális plazmasejtek elpusztítása, hogy minél hamarabb csökkenteni lehessen a kóros könnyưlánc-termelést, és vissza lehessen szorítani az érintett szervek károsodását [37]. A plazmasejtes betegség a jóindulatúnak tekinthetô MGUS-állapottól a myeloma multiplex jelenlétéig terjedhet. Az AL-amyloidosisos esetek nagy részében MGUS-állapot áll fenn, azonban 10-15\%-ban myeloma multiplex igazolódik. Az AL-amyloidosis három csoportba osztható: alacsony, közepes és magas rizikójú betegek.

Alacsony rizikójúak azok, akik jó általános állapotban vannak, az NT-proBNP $<5000 \mathrm{ng} / \mathrm{ml}$, cardialis troponin $\mathrm{T}<0,06 \mathrm{ng} / \mathrm{ml}$, nincs jelentős mellkasi folyadék, autonóm neuropathia vagy amyloidhoz köthető gastrointestinalis vérzés és jó a vesemúködés. Az összes AL-amyloidosisos beteg közül ebbe a csoportba tartozik a betegek 15-20\%-a. Ezek a betegek a nagy dózisú melphalan és autológ őssejt-transzplantáció jelöltjei [38-40]. Az autológ transzplantáció kapcsán nagyon fontos a megfelelő betegek kiválasztása, ebben segítséget nyújtanak a kardiológiai biomarker-paraméterek, így a kezeléssel összefüggő halálozás kevesebb mint $10 \%$ lehet $[38,39]$.

$\mathrm{Az}$ intermedier csoportba tartozók kombinált kemoterápiában részesülnek. Randomizált vizsgálati eredmények nem állnak rendelkezésre, de kezelési opcióként orális melphalan és dexamethason kombináció vagy rizikóadaptált formában cyclophoshamid, thalidomid és dexamethason (CTD) kombináció az elfogadott [41]. CTD-kombináció esetén 65-75\%-os válaszarány érhető el három-négy hónapon belül [41, 42]. Bortezomib, cyclophosphamid és dexamethason kombinációval $>90 \%$-os válaszadási arányt mutat indukciós kezelésként, 60\%-ban nagyon jó parciális válasz (very good partial response - VGPR) vagy komplett válasz elérésével [43, 44]. Ez a kombináció gyors és mély választ képes elöidézni, az érintett szervek, köztük a szív funkciójának javulását. Ezek alapján az intermedier csoportban ez az elsődleges választandó kezelés. Vizsgálatok folynak a bortezomib kiegészítésével melphalan és dexamethason esetén, valamint új proteoszómagátlók, mint a carfilzomib vagy ixazomib eredményességét illetően. A lenalido- mid és pomalidomid új típusú immunmodulátorok, elsősorban alkilálószerekkel kombinációban [45-47] és relabált vagy refrakter esetekben jönnek szóba.

Magas rizikójú betegek esetén egyik kombináció sem bizonyult jobbnak a másiknál [29]. Az elmúlt évtizedben jelentős fejlődés volt megfigyelhető a myeloma multiplex kezelésben, ami AL-amyloidosis kapcsán is javulást hozott [48], az átlagos túlélés megduplázódott. Azonban a betegek $25 \%$-a továbbra is a betegséghez köthető szövődmények miatt hunyt el. A bortezomibalapú terápia indukciós vagy konszolidációs kezelés esetén több mint 90\%-os VGPR-arányt képes elérni [49, 50].

\section{Eszközös lehetőségek}

Pacemaker és ICD (beültethető cardioverter defibrillátor) nem minden esetben előzheti meg a hirtelen szívhalált, mert gyakran elektromechanikus disszociáció eredménye $[31,51]$. Az ICD előnye nem bizonyított, a magas küszöbérték tûnik jó választásnak a beállítás kapcsán [51].

\section{Következtetés}

A szívamyloidosis továbbra is kihívást jelent mind a diagnózis, mind a kezelés szempontjából. Amennyiben a tünetek felvetik a betegség lehetőségét, szisztémás kivizsgálás feltétlenül indokolt. Több szervet érintő betegség lévén, nem feltétlenül hematológus találkozik először a tünetekkel. Rendkívül fontos a kórkép gyors felismerése, kivizsgálása és a kezelés megkezdése. Szívérintettség gyanúja esetén az EKG, biomarker-vizsgálatok, az echokardiográfia és a cardialis MR-vizsgálat adhat pontosabb képet. Szövettani mintavétel minden esetben indokolt, a mintát hematológiai területen tapasztalt patológussal célszerú vizsgáltatni az amyloid típusának pontos meghatározása céljából. Mivel szisztémás betegségről van szó, a mintavétel bármelyik érintett szervből, szövetből megtörténhet. A könnyebb hozzáférés és kevesebb szövődmény tekintetében a szubkután zsírszövetből vett minta jó választás lehet. Számos klinikai vizsgálat foglalkozik új támadáspontú gyógyszerek fejlesztésével jelenleg is. Habár az elmúlt években a kezelési lehetőségek sokat javultak, előrehaladott szívamyloidosis fennállása esetén a túlélés még mindig igen rossz.

Anyagi támogatás: A szerzók anyagi támogatásban nem részesültek.

Szerzői munkamegosztás: Valamennyi szerző részt vett a közlemény megírásában, valamint az előzetes irodalmi adatok feldolgozásában.

Érdekeltségek: A szerzőknek nincsenek érdekeltségeik. 


\section{Irodalom}

[1] Sipe JD, Benson MD, Buxbaum JN, et al. Nomenclature 2014: Amyloid fibril proteins and clinical classification of the amyloidosis. Amyloid 2014; 21: 221-224.

[2] Esplin BL, Gertz MA. Current trends in diagnosis and management of cardiac amyloidosis. Curr Probl Cardiol. 2013; 38: 53 96.

[3] Pepys MB, Rademacher TW, Amatayakul-Chantler S, et al. Human serum amyloid $\mathrm{P}$ component is an invariant constituent of amyloid deposits and has a uniquely homogeneous glycostructure. Proc Natl Acad Sci. USA 1994; 91: 5602-5606.

[4] Tan SY, Pepys MB. Amyloidosis. Histopathology 1994; 25 403-414.

[5] Merlini G. CyBorD: stellar response rates in AL amyloidosis Blood 2012; 119: 4343-4345.

[6] Lachmann HJ, Goodman HJ, Gilbertson JA, et al. Natural history and outcome in systemic AA amyloidosis. N Engl J Med. 2007; 356: 2361-2371

[7] Liao R, Jain M, Teller P, et al. Infusion of light chains from patients with cardiac amyloidosis causes diastolic dysfunction in isolated mouse hearts. Circulation 2001; 104: 1594-1597.

[8] Shi J, Guan J, Jiang B, et al. Amyloidogenic light chains induce cardiomyocyte contractile dysfunction and apoptosis via a noncanonical p38alpha MAPK pathway. Proc Natl Acad Sci. USA 2010; 107: 4188-4193.

[9] Merlini G, Lousada I, Ando Y, et al. Rationale application and clinical qualification for NT-proBNP as a surrogate end point in pivotal clinical trials in patients with AL amyloidosis. Leukemia 2016; 30: 1979-1986.

[10] Kumar S, Dispenzieri A, Lacy MQ, et al. Revised prognostic staging system for light chain amyloidosis incorporating cardiac biomarkers and serum free light chain measurements. J Clin Oncol. 2012; 30: 989-995.

[11] Grogan M, Dispenzieri A, Gertz MA. Light-chain cardiac amyloidosis: strategies to promote early diagnosis and cardiac response. Heart 2017; 103: 1065-1072.

[12] Dispenzieri A, Dingli D, Kumar SK, et al. Discordance between serum cardiac biomarker and immunoglobulin-free light-chain response in patients with immunoglobulin light-chain amyloidosis treated with immune modulatory drugs. Am J Hematol. 2010; 85: 757-759.

[13] Palladini G, Foli A, Milani P, et al. Best use of cardiac biomarkers in patients with $\mathrm{AL}$ amyloidosis and renal failure. Am J Hematol. 2012; 87: 465-471

[14] Cheng ZW, Tian Z, Kang L, et al. Electrocardiographic and echocardiographic features of patients with primary cardiac amyloidosis. Zhonghua Xin Xue Guan Bing Za Zhi 2010; 38: 606609.

[15] Murtagh B, Hammill SC, Gertz MA, et al. Electrocardiographic findings in primary systemic amyloidosis and biopsy-proven cardiac involvement. Am J Cardiol. 2005; 95: 535-537.

[16] Patel AR, Dubrey SW, Mendes LA, et al. Right ventricular dilation in primary amyloidosis: an independent predictor of survival. Am J Cardiol. 1997; 80: 486-492.

[17] Porciani MC, Lilli A, Perfetto F, et al. Tissue Doppler and strain imaging: a new tool for early detection of cardiac amyloidosis. Amyloid 2009; 16: 63-70.

[18] Tsang W, Lang RM. Echocardiographic evaluation of cardiac amyloid. Curr Cardiol Rep. 2010; 12: 272-276.

[19] Bellavia D, Pellikka PA, Abraham TP, et al. Evidence of impaired left ventricular systolic function by Doppler myocardial imaging in patients with systemic amyloidosis and no evidence of cardiac involvement by standard two-dimensional and Doppler echocardiography. Am J Cardiol. 2008; 101: 1039-1045.

[20] Falk RH, Alexander KM, Liao R, et al. AL (light-chain) cardiac amyloidosis: a review of diagnosis and therapy. J Am Coll Cardiol. 2016; 68: 1323-1341.
[21] Sengupta PP, Tajik AJ, Chandrasekaran K, et al. Twist mechanics of the left ventricle: principles and application. JACC Cardiovasc Imaging 2008; 1: 366-376.

[22] Nemes A, Kalapos A, Domsik P, et al. Left ventricular rotation and twist of the heart. [A szív bal kamrai rotációja és csavarodása.] Orv Hetil. 2012; 153: 1547-1551. [Hungarian]

[23] Ammar KA, Paterick TE, Khandheria BK, et al. Myocardial mechanics: understanding and applying three-dimensional speckle tracking echocardiography in clinical practice. Echocardiography 2012; 29: 861-872.

[24] Nemes A, Kalapos, A, Domsik P, et al. Three-dimensional speckle-tracking echocardiography - a further step in the non-invasive three-dimensional cardiac imaging. [Háromdimenziós speckletracking echokardiográfia - egy újabb lépés a noninvazív háromdimenziós cardialis képalkotásban.] Orv Hetil. 2012; 153: 1570-1577. [Hungarian]

[25] Nemes A, Földeák D, Domsik P, et al. Different patterns of left ventricular rotational mechanics in cardiac amyloidosis-results from the three-dimensional speckle-tracking echocardiographic MAGYAR-Path Study. Quant Imaging Med Surg. 2015; 5: 853857.

[26] Vogelsberg H, Mahrholdt H, Deluigi CC, et al. Cardiovascular magnetic resonance in clinically suspected cardiac amyloidosis: noninvasive imaging compared to endomyocardial biopsy. J Am Coll Cardiol. 2008; 51: 1022-1030.

[27] Maceira AM, Joshi J, Prasad SK, et al. Cardiovascular magnetic resonance in cardiac amyloidosis. Circulation 2005; 111 : 186193.

[28] Banypersad SM, Moon JC, Whelan C, et al. Updates in cardiac amyloidosis: a review. J Am Heart Assoc. 2012; 1: e000364.

[29] Wechalekar A, Schonland SO, Kastritis E, et al. European collaborative study of treatment outcomes in 347 patients with systemic AL amyloidosis with Mayo stage III disease. Blood 2011; 118: 995.

[30] Dispenzieri A, Gertz MA, Kyle RA, et al. Serum cardiac troponins and $\mathrm{N}$-terminal pro-brain natriuretic peptide: a staging system for primary systemic amyloidosis. J Clin Oncol. 2004; 22: 3751-3757.

[31] Palladini G, Barassi A, Klersy C, et al. The combination of highsensitivity cardiac troponin $\mathrm{T}$ (hs-cTnT) at presentation and changes in $\mathrm{N}$-terminal natriuretic peptide type B (NT-proBNP) after chemotherapy best predicts survival in AL amyloidosis. Blood 2010; 116: 3426-3430.

[32] Kristen AV, Giannitsis E, Lehrke S, et al. Assessment of disease severity and outcome in patients with systemic light-chain amyloidosis by the high-sensitivity troponin T assay. Blood 2010; 116: 2455-2461.

[33] Dispenzieri A, Lacy MQ, Katzmann JA, et al. Absolute values of immunoglobulin free light chains are prognostic in patients with primary systemic amyloidosis undergoing peripheral blood stem cell transplantation. Blood 2006; 107: 3378-3383.

[34] Palladini G, Dispenzieri A, Gertz MA, et al. New criteria for response to treatment in immunoglobulin light chain amyloidosis based on free light chain measurement and cardiac biomarkers: impact on survival outcomes. J Clin Oncol. 2012; 30: 45414549 .

[35] Sousa M, Monohan G, Rajagopalan N, et al. Heart transplantation in cardiac amyloidosis. Heart Fail Rev. 2017; 22: 317-327.

[36] Gertz MA, Lacy MQ, Dispenzieri A, et al. Stem cell transplantation for the management of primary systemic amyloidosis. Am J Med. 2002; 113: 549-555.

[37] Comenzo RL, Reece D, Palladini G, et al. Consensus guidelines for the conduct and reporting of clinical trials in systemic lightchain amyloidosis. Leukemia 2012; 26: 2317-2325.

[38] Gertz MA, Lacy MQ, Dispenzieri A, et al. Trends in day 100 and 2 -year survival after auto-SCT for AL amyloidosis: outcomes before and after 2006. Bone Marrow Transplant. 2011; 46: 970975 . 
[39] Gertz MA, Lacy MQ, Dispenzieri A, et al. Refinement in patient selection to reduce treatment-related mortality from autologous stem cell transplantation in amyloidosis. Bone Marrow Transplant. 2013; 48: 557-561.

[40] Comenzo RL, Gertz MA. Autologous stem cell transplantation for primary systemic amyloidosis. Blood 2002; 99: 4276-4282.

[41] Wechalekar AD, Goodman HJ, Lachmann HJ, et al. Safety and efficacy of risk-adapted cyclophosphamide, thalidomide, and dexamethasone in systemic AL amyloidosis. Blood 2007; 109: 457-464.

[42] Palladini G, Perfetti V, Obici L, et al. Association of melphalan and high-dose dexamethasone is effective and well tolerated in patients with $\mathrm{AL}$ (primary) amyloidosis who are ineligible for stem cell transplantation. Blood 2004; 103: 2936-2938.

[43] Venner CP, Lane T, Foard D, et al. Cyclophosphamide, bortezomib, and dexamethasone therapy in AL amyloidosis is associated with high clonal response rates and prolonged progressionfree survival. Blood 2012; 119: 4387-4390.

[44] Mikhael JR, Schuster SR, Jimenez-Zepeda VH, et al. Cyclophosphamide-bortezomib-dexamethasone (CyBorD) produces rapid and complete hematologic response in patients with $\mathrm{AL}$ amyloidosis. Blood 2012; 119: 4391-4394.

[45] Moreau P, Jaccard A, Benboubker L, et al. Lenalidomide in combination with melphalan and dexamethasone in patients with newly diagnosed AL amyloidosis: a multicenter phase $1 / 2$ doseescalation study. Blood 2010; 116: 4777-4782.

[46] Kastritis E, Terpos E, Roussou M, et al. A phase $1 / 2$ study of lenalidomide with low-dose oral cyclophosphamide and low- dose dexamethasone ( $\mathrm{RdC}$ ) in $\mathrm{AL}$ amyloidosis. Blood 2012; 119: 5384-5390.

[47] Palladini G, Russo P, Milani P, et al. A phase II trial of cyclophosphamide, lenalidomide and dexamethasone in previously treated patients with AL amyloidosis. Haematologica 2013; 98: 433436.

[48] Gertz MA, Dispenzieri A. Immunoglobulin light-chain amyloidosis: growing recognition, new approaches to therapy, active clinical trials. Oncology 2012; 26: 152-161.

[49] Landau H, Hassoun H, Rosenzweig MA, et al. Bortezomib and dexamethasone consolidation following risk-adapted melphalan and stem cell transplantation for patients with newly diagnosed light-chain amyloidosis. Leukemia 2013; 27: 823-828.

[50] Sanchorawala V, Brauneis D, Shelton AC, et al. Induction therapy with bortezomib followed by bortezomib-high dose melphalan and stem cell transplantation for light chain amyloidosis: results of a prospective clinical trial. Biol Blood Marrow Transplant. 2015; 21: 1445-1451

[51] Kristen AV, Dengler TJ, Hegenbart U, et al. Prophylactic implantation of cardioverter-defibrillator in patients with severe cardiac amyloidosis and high risk for sudden cardiac death. Heart Rhythm 2008; 5: 235-240.

(Földeák Dóra Melinda dr., Szeged, Semmelweis u. 8., 6725 e-mail: dora.foldeak@gmail.com)

\section{NOTA \\ Új fejlesztés az egészségügyben dolgozók, tanulók részére!}

A magyar nyelvứ szakirodalmi keresőszolgáltatás

\section{Mi a NOTA? \\ Napivizit Orvosi Tudástár Alkalmazás}

Mit tud a NOTA portál?

Megkönnyíti a magyar nyelvű szakirodalmi források keresését.

Eszköztöl függetlenül, akár okostelefonról, a betegágy mellett állva is használható.

\section{Miben kereshet a NOTA-val?}

Az Akadémiai Kiadó folyóirataiban: Orvosi Hetilap, Magyar Sebészet, Mentálhigiéné és Pszichoszomatika.

Más kiadók magyar nyelvú szakfolyóirataiban: pl. Lege Artis Medicinae, Hypertonia és Nephrologia, Ideggyógyászati Szemle.

A hatályos szakmai irányelvekben.

Magyar nyelvű kérdésekre adott ango nyelvű találatokban, a PubMeden.

\section{nota.hu}

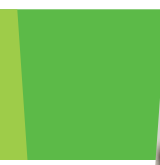

\section{email: dora.foldeakggmail.com)}

.

